\title{
Problems of definition and classification of fantasy: Western European and Slavonic perspectives
}

\author{
Olga Ryzhchenko, ${ }^{1, *}$ \\ ${ }^{1}$ Kharkiv National University of Radio Electronics, 61166, 14 Nauki ave., Kharkiv, Ukraine
}

\begin{abstract}
The article deals with the problem of definition and classification of literary works marked as fantasy. Being quite a modern genre, fantasy, on the one hand, has become quite a popular literature among groups of people of different ages and occupations that leads to the rising attention of theorists of literature and literary critics. But, on the other hand, this literary genre is still not studied and described well enough. Therefore, literary studies do not have conventional definition or classification of the genre. Examining famous fantasy works by J. Tolkien ("The Lord of the Rings"), J. Martin ("The Song of Ice and Flame") and M. and S. Dyachenko ("Wanderers"), we managed to accentuate typical featured of the genre and define it. Comparing Western European and Slavonic fantasy, we came to a conclusion that this genre combines such necessary features as mythological basis, adventure intrigue, the division of the heroes into possessing superpowers and not possessing such ones, the presence of magical artefacts, opposition to the evil on a global scale. Speaking about classification of the genre we can point out two subgroups such as leaning towards the mythological basis and folklore and leaning towards the historical basis.
\end{abstract}

At the present stage of the development of literature, the so-called "pure genre" as such has disappeared, giving way to various mixes that combine the features of different and sometimes incompatible genres. The comparatively young genre of fantasy, the official developmental history of which is less than one hundred years old, is not an exception. Considering that its definition and classification remain actual problems, which have not been the objects of serious research for a long time.

It seems to us quite appropriate to divide fantasy according to its territorial basis into the Western European and Slavonic ones, because mythology peculiar for each particular territory played an important role in the development of the genre. In this regard, it will be rational to examine the works of this genre separately, at the same time highlighting their similar features.

The article by O. K. Yakovenko "Genre features of fantasy" [1] presents an analysis of the dictionary definitions of fantasy, which reveal the dynamics of the development of the genre definition from 1991 to 2005 . The author first indicates the definitions of the genre,

* Corresponding author: eradis80@ rambler.ru 
given in Western dictionaries and then in Slavonic, at the end combining the definitions and making conclusions about the characteristic features of the genre. As the researcher points out, the first definitions of the genre were based more on the etymology of the word "fantasy", defining the genre itself as "a story that someone creates from their imagination and that is not based on reality" [2, p. 516]. However, such a definition does not reflect all the key components of the fantasy genre. Moreover, it can be applied to thriller or mystery, which leads to the confusion of different concepts, rather than to the delimitation of genres. Consequently, such definition of fantasy, based only on the imagination, cannot be taken as the basis.

According to the Longman Dictionary of English Language and Culture (2005), the genre of fantasy is defined as "stories about imaginary worlds which often involve magic. The characters are often searching for good, and they usually fight with swords rather than modern weapons" [3, p. 492]. Proceeding from this, we can distinguish the following necessary components of the work of this genre, namely, the indispensable presence of magic, an object for fighting with the evil and the sword as an indispensable weapon for the struggle. Unlike the first definitions, the later definition of fantasy allows us to define the genre as a product based on unreal (magical) events that occur in the unreal world (the world of magic), which originates in the theory of possible worlds by D. Lewis [4], which pointed to the presence of the actual world (our world) and a huge number of other worlds.

S. N. Belokurova defines the genre of fantasy as "works depicting fictional events in which the main role is played by the irrational, mystical basis, and worlds which existence can't be explained logically $<\ldots>$ a peculiar combination of a fairy tale, a fantasy and an adventure chivalric romance" [5, 190]. And the First Definition Great Encyclopedic Dictionary (2006) points out fantasy as "a school in literature, cinema, computer games, etc., including works of different genres which characters exist in the relative social and natural environment, in the "the secondary world", created by the author's imagination, for the formation of which the whole arsenal of fairy tales, legends and myths of different people can be used" [6, p. 1939].

As it can be seen from the above definitions, the Western direction as the basic characteristics of the genre identifies surreal events taking place in the surreal world, which implies the presence of magic, as well as the division of the whole world into the real one and the "other one". At the same time, the Slavonic definition of fantasy adds a mixture of tales, legends and myths as the basis of fantasy.

However, even later definitions of the genre, both Western and Slavonic, do not allow us to compile a comprehensive picture that would allow us to fully and accurately reflect all the necessary components of the genre. As we can see, the presence of a mystical reality, the so-called "another world," sets apart works of fantasy from the stream of similar literary works. The statement about the combination of fantasy and adventure novel, as well as the combination of works of different genres, initially points to the borderline of this genre. That is to say, the genre of fantasy combines the features of other genres, thus representing a kind of "mix" of adventure, mystical and fantastic literature. And, consequently, it is not always possible to draw a clear line between fantasy and other genres. In this regard the problem of determining the genre of fantasy remains open upon to this day.

We will make an attempt to identify the main, in our view, components of the genre and offer its definition, based on the general features of Western and Slavonic fantasy. As an example, let's take the works of Ukrainian and foreign literature: the classical trilogy of the father-founder of the genre J. Tolkien "The Lord of the Rings", novels from the cycle "The Song of Ice and Flame" by J. Martin and the "Wanderers" cycle ("The Gatekeeper") by Ukrainian novelists Maryna and Serhiy Dyachenko.

From our point of view, it is reasonable to highlight the following necessary components of the genre of fantasy: 
1. The mythological basis.

The key factor in the works of fantasy is the presence of magic and the supernatural, creatures or phenomena that are present in the myths and legends of the people of the world. The ancient gods possessed superpowers and controlled not only the phenomena of nature but people's destiny as well. This "power" later migrated to works of fantasy as a magical effect. But let's not forget that the roots of magic lie precisely in ancient mythology. The works of fantasy are based mainly on ancient mythology. So Western fantasy is based, fundamentally, on the Celtic epic, while Slavonic fantasy is rooted in the Slavonic. The use of original legends, myths and legends, as well as folk tales was reflected in the relatively young genre of fantasy.

Celtic epic had a huge impact on the formation of Western fantasy. If you remember the legends about King Arthur, then the wizard Merlin who helped the king to fight the evil comes to mind. Slavonic epic abounds with a huge number of magical creatures. Baba Yaga - a typical representative of fairy tales can be given as a vivid example of a Slavonic magician.

The presence of magic in the works of Ukrainian fantasy writers and Western writers is indisputable: the wizards live side by side with ordinary people: the white magician Gendalf ("The Lord of the Rings"), the Red Woman ("The Song of Ice and Flame"), "the magician who is not a magician" Rual Ilmarranen ("The Gatekeeper") practise magic to achieve their own goals.

2. An adventure intrigue.

There is no doubt that the works of fantasy have a dynamic plot, the events in them are rapidly developing. Therefore, it is fair to say that fantasy works borrowed its intrigue from adventure novels. In the classical example of the genre - the trilogy of J. Tolkien "The Lord of the Rings" heroes constantly fall into difficult situations. Moreover, the author divided the narrative into several concentric circles in order to constantly keep the reader in suspense. Accordingly, dynamically developing adventure intrigue is an integral part of a typical work of fantasy.

Talking about the work of Maryna and Serhiy Dyachenko, the cycle "The Wanderer", everything is somehow different. The intrigue in the first novel of the cycle "Wanderers" is built on the journey of the main character, who faces a moral choice. In this case, we trace the moral experiences of the hero rather than his adventures. The authors try to intrigue the reader with the question of who is the Gatekeeper, who must allow the Third Force, the universal evil, which intends to destroy the established world order, in. The hero's way is his redemption, awareness of himself and acceptance of responsibility for what was done in the past. Such main character's development can also be found in the trilogy "The Lord of the Rings". The story of Frodo and Sam is the story of the temptation that heroes give in, it's the story of retribution for the deeds that are clearly traced in the end of the trilogy: Frodo lost something, and Sam got something.

Chivalric romance had a huge influence on the development of the genre of Western fantasy. Knights of the Round Table were present in the Celtic epic about King Arthur. This is the reason for the exclusivity of the protagonist, since a fighter with the evil must possess the qualities of an ideal person - a "noble knight". Regarding to Slavonic fantasy, it can be noted that the Slavonic epics about the heroes, destined to protect the homeland from the conquerors have a slightly different shade of heroic courage is put on the first place. Therefore, in our opinion, it is not entirely expedient to point out the chivalric novel as the main source of borrowing, since it is not a characteristic feature of Slavonic fantasy, but the element of the adventure novel which unites these two directions.

3. The division of the heroes into possessing superpowers (magicians and magical beings) and not possessing such ones (ordinary people. 
The classical method of dividing the heroes in any work of any genre is the opposition of the hero and antagonist. The genre of fantasy is not an exception. However, in this genre an attempt is made to divide the heroes according to the principle of the presence or absence of magical abilities. In this case, antagonists often have magical abilities, which complicates the task of heroes-magicians and heroes-non-magicians.

We believe, the idea of so-called "another world" as a necessary component of the genre rather reflects the division of the heroes into two groups. Almost in all works of fantasy genre there coexist heroes endowed with magical abilities, as well as creatures and phenomena of magical nature, with ordinary people not endowed with such abilities. If we take as a basis the same classical example, the trilogy by J. Tolkien, we will be able to identify several groups of heroes:

- Heroes with magical powers (wizards Gandalf and Saruman);

- Mythical creatures (elves and dwarfs, orcs);

- Not endowed with magical abilities and human-like (Aragorn, Boromir, Hobbits Frodo and Bilbo, Sam, Pippin and Merry).

Talking about the famous cycle by J. Martin, we can point out that the author included not only witches but also magical creatures such as dragons. His heroes can be classified into heroes possessing special abilities, not possessing special abilities ordinary people and magical creatures: ordinary people (the Lannisters, the Martells, Brienne of Tarth); magical creatures (White Walkers, giants, dragons, direwolves).

Heroes with special abilities: heroes with special powers such as controlling other living beings (Daenerys Targaryen); wargs who can control other animals by the force of their mind (the Starks and Jon Snow); wizards and witches (The Red Woman, the Faceless); magical nature creatures connected with the nature (Three-Eyed Raven).

The world in the cycle is divided into different kingdoms and a special area, separated by the Wall. But still we do not think that here we face with the idea of "real world" and "another world".

In the cycle "Wanderers" of Ukrainian fantasy writers, the world is united and universal, this world identifies wizards and magicians as supernatural beings, ordinary people are afraid of. The magicians Lart Legyar and Balthasar Est live an ordinary life among people. An ordinary person Damir, who does not have magical abilities, is in the service of Lart Legyar and is proud of his special status. Wizards represent a high caste, such as ancient priests or shamans. In this connection, one can point to the fixation of the work of Ukrainian fantasy writers to historical roots.

Prof. V. Propp's "Morphology of the Folktale" has long been one of the fundamental treatises of folklore studies, presenting the author's discovery of a uniform structure of the folktale plot. In his work the famous Russian folklore philologist points out that every hero in a fairy tale has a function, and many functions are united to the circles. So he distinguishes:

1. The circle of action of the anagonist (pest);

2. The circle of the donor (provider);

3. The circle of the assistant's action;

4. The circle of action of the desired character;

5. The circle of the sender;

6 . The circle of action of the hero;

7. The circle of the action of the false hero.

As a result, the scientist comes to the conclusion that there are seven types of characters in the tale [7, pp. 72-73]. Such an attempt to split the fantasy heroes into action circles in accordance with the performed function can be undertaken in our further research of the problem. 
4. The presence of magical artefacts (in addition to the sword as a necessary tool to fight with the evil).

In typical works of fantasy, wizards usually possess special artefacts that emphasize their special status. Magic items such as the magical staves of Gandalf and Saruman, One Ring to Rule Them All, or the magical sword Sting of Frodo from the trilogy of J. Tolkien help both magicians and ordinary people in difficult and sometimes desperate, at first sight, situations.

Maester Luwin says to Bran Stark that magic once was a mighty force in the world, but not anymore, but definitely he is not right. Maybe that is why J. Martin does not provide his heroes with a variety of magical tools to oppose the world of the dead. The only things which can be found there are magical dragon eggs (they are remarkable by their unique status) and dragonglass to kill the White Walkers (which is not magical because it is obsidian or volcanic glass). But still magic has started to return to the world as dragons were born.

Ukrainian writers Marina and Serhiy Dyachenko do not provide their heroes with magical devices as well. But still it is typical and well-known that magicians use different spells to take magical actions. The Red Woman from "The Song of Ice and Flame" is not an exception. Likewise, Lart Legyar and Balthasar Est ("Wanderers") use them. They also try to use other special magical things such as magical water glass and magical locket which can predict the danger and show the future or turn rusty to show that The Third Force is threatening.

These special magical artefacts emphasize the special status of the heroes, their power over other people and natural phenomena. Moreover, they are meant to help them in their fight as they have to be braver and stronger than ordinary people.

5. Opposition to the evil of a global scale.

In the works of fantasy, genre heroes are not only forced to resist anti-heroes, but also to fight with the so-called "Great Evil". Dark forces are represented mainly as something that threatens the entire world order, something destructive and all-consuming, seeking to destroy all accepted canons. In this regard, counteracting evil is the main task of heroes, who are forced to risk their lives for the sake of the triumph of the good. They literally save the whole world, because the evil in the works of fantasy has a universal scale.

The Fellowship of the Ring joined together to start the battle against Sauron and his army not to let the Dark Years repeat. They need to risk their lives but safe their world from this evil threatening it. If Sauron wins all the free people such as elves and dwarfs, hobbits and people will suffer that is why the heroes have to sacrifice their lives if need be to protect the world.

The White Walkers or the Army of the Dead want to capture the territory of the alive and even more to turn all the people into the dead as well. So J. Martin describes the global battle of the dead with the alive, death with life when the price is too high and the result of this battle will be vital. If the dead win life will be destroyed, not even life but hope as well. The world will face its regress and complete destruction.

"The Third Force" wants to destroy the world order and replace it into chaos and laxity. And "The Gatekeeper" is destined to open the door to it and let it in. This Force is based on the hatred and all negative feelings which refer to people so to keep the world in order the main hero has to cope with these feelings. But still this struggle is global because the destiny of the whole world depends on it.

As we can see heroes have to think not about their own necessities and likes but about the future of all people who live and will live after. Their lives can seem small drops but the whole stream relies on them. They do not struggle for themselves but for the others and they may get nothing as a reward for their attempts to protect the whole world. 
Thus, if we try to put together all the above-stated components of the genre, we will be able to derive the following definition:

Fantasy is a literary genre, singled out from adventure fiction, while retaining its main intrigue and taking mythological images as the basis. The necessary components of the genre of fantasy is the presence of magic and the supernatural, as well as the division of heroes into those who possess supernatural abilities and those who do not possess them, who jointly resist the Dark Forces, using magical artefacts.

Another problematic issue which still remains open is the problem of classifying of works of this genre. In his work "Genre Classification of Contemporary Russian Fantasy: Setting up the Problem", I. V. Lebedev points out that there are several approaches to the classification of fantasy. The first approach involves the classification of fantasy by the type of adventure, since "in any fantasy work, an adventure rather than a fantasy component comes to the fore" [8, p. 57].

Classifying fantasy according to the problematic-thematic principle, R. Shidfar distinguishes the following types: heroic (epic, Tolkien); folklore and fairy-tale, "where the characters live in the real world, populated by characters from myths"; fantasy of "sword and magic" (it can also be called a heroic-epic and adventurous fantasy); myth-forming, where "a world with its own mythology is created" [9, 87].

S. Alekseev and M. Batshev classified fantasy according to the thematic principle, highlighting: "classical fantasy", where "the action takes place in some conditional mythical past, in our world or in parallel reality"; historical fantasy; scientific fantasy, connecting science fiction with fantastic assumptions [10, 83].

Y. Afanasyeva proposes the following classification of fantasy: on the basis of the plot (epic, romantic, mystical, "black", "mythological"); on the national specifics (Celtic, Mongolian, Scandinavian, Slavonic, etc.); by the time of the action (historical and pseudohistorical fantasy, urban (modern) fantasy and fantasy about the distant future); according to the axiological aspect (heroic fantasy with the most positive evaluation and "satirical" fantasy, denying the heroic, humorous); according to the worldview aspect (Christian or sacred fantasy, techno-magic (it's scientific fantasy) and philosophical thriller); by the addressee (adult and children) [9].

As I.V. Lebedev aptly notes all abovementioned classifications have some faults and they can't be taken as incontestable and exclusively right. So the problem of classification is about to be solved. But some additional approaches can be suggested accordingly.

We believe that works of fantasy genre can be divided into two large subgroups:

1. Leaning towards the mythological basis and folklore;

2. Leaning towards the historical basis.

Fantasy works that lean towards the mythological basis involve a large number of fantastic phenomena and creatures. For example, in the novel "Bastard" by Ukrainian fantasy writers Marina and Serhiy Dyachenko, heroes overcome many obstacles, such as magical traps "Zheltomara" and "Zazhora" that indicates the use of a large number of fabulous material.

At the same time in the novel "Scar", the second part of the "Wanderers" cycle, the authors use the minimum number of "magical special effects", and the magicians in the novel are engaged in the usual "human affairs": they give lectures at the university and write scientific works on the history of magicians and magic. And only the spell, imposed on the vain and arrogant hero Egert Soll and the sacrifice of the dean of the university indicate the presence of a magical effect in the novel. As for the rest, it is a typical historical work, describing the history of self-control and struggle for his feelings of an ordinary person, not endowed with magical abilities. In this case, magic is a collection of certain knowledge and life experience that points to the historical basis of the work (if you recall history, then in the Middle Ages knowledge was considered an attribute of magicians 
and sorcerers, and the history of the Inquisition is an additional confirmation, reflected in the image of the ministers of the cult of the sacred ghost Lash in the novel).

The cycle about the battle for the Iron Throne of Seven Kingdoms resemble historical battles for the same purpose of Medieval kings and princes. Despite some magical elements in the novels J. Martin has a tendency to describe people's desire to rule and protect their rights. So it may seem reasonable to mention that J. Martin's works as well as Dyachenko's novels pay great attention to describing the psychological side of their heroes, their positive and negative features, their struggle not only with their enemies but with themselves as well. The problem of "moral choice" is quite a common thing for their works. Thus we can distinguish one more type of fantasy - "psychological fantasy", fantasy of people and characters.

Classical trilogy by J. Tolkien includes all necessary features of mythological fantasy, magic and magical phenomena are to be met everywhere and it is impossible to exclude them. The heroes are to fight with magical creatures and try to avoid magical traps. The element of psychological novel is to be found as well but the main thing in the trilogy is adventure not people's souls and feelings.

Having analyzed the most typical features of fantasy novels to define the genre and classify it, we still can say that there is a lot to be done in this field and a lot to be described and defined. Fantasy as a literary genre is quite a challenging one as it combines the features of other genres. Moreover, Romantic period has influenced it greatly but this problem is still to be solved in the future.

\section{References}

1. O. Yakovenko, Bul. of the Irkutsk St. Ling. Univ., 1 (2008)

2. C. Cobuild, English language dictionary (Clays Ltd, London, 1991)

3. Longman dictionary of English language and culture (Person Ed. Limited, Harlow, 2005)

4. D. Lewis, Philosoph. Pap., 1 (1983)

5. S. Belokurova. Dictionary of literary terms (Parity, St. Petersburg, 2006)

6. The first explanatory large encyclopedic dictionary (Ripol-Noreint, St. Petersburg, Moscow, 2006)

7. V. Propp, Morphology of the folktale (Moscow, 1969)

8. I. Lebedev, Innovative Science, 7 (2015)

9. Y. Afanasyeva, Genre of fantasy: the problem of classification (2009)

10. S. Alekseev, M. Batchev, Book Industry, 1 (1997) 